\title{
Pelatihan Pengembangan Usaha Jagung dan Singkong Bagi Masyarakat di Desa Pringgesele Lombok Timur
}

\author{
Irwan Suriadi*, Siti Sriningsih, Hailudin, Gusti Ayu Arini, \\ Baiq Saripta Wijimulawiani
}

Program Studi Ekonomi Pembangunan Fakultas Ekonomi dan Bisnis, Universitas Mataram

\section{Article history}

Received: 30-12-2020

Revised: 27-03-2021

Accepted: 24-06-2021

*Corresponding Author: Irwan Suriadi,

Program Studi Ekonomi

Pembangunan Fakultas

Ekonomi dan Bisnis,

Universitas Mataram,

Mataram, Indonesia;

Email:

irwansuryadi@unram.ac.id

\begin{abstract}
The purpose of this program is to help partners to process corn and cassava agricultural products from raw products into high value and high value added products that will increase income for the people in the Pringgese village. The method used in achieving the objectives of this activity is by conducting training and assistance. The results of community service activities are that people in the village of Pringgesele can develop high-value processed corn and cassava products so as to increase the income of the people in the village of Pringgesele by processing raw materials in the form of corn and cassava into finished goods that have added value and can open jobs for the community around with the existence of processed corn and cassava products because so far the yield of agricultural products in the form of corn and cassava is quite a lot in the village of Pringesele.
\end{abstract}

Keywords: corn and cassava; product processing; product packaging

Abtrak: Tujuan program ini adalah untuk membantu mitra adalah untuk mengolah produk pertanian jagung dan singkong dari produk mentah menjadi produk jadi yang bernilai tinggi dan memiliki nilai tambah sehingga akan meningkatkan pendapatan bagi masyarakat di desa pringgese. Metode yang digunakan dalam mencapai tujuan kegiatan ini adalah dengan melakukan pelatihan dan pendampingan. Hasil dari kegiatan pengabdian kepada masyarakat ini adalah masyarakat di desa pringgesele dapat mengembangkan produk olahan jagung dan singkong yang bernilai tinggi sehingga menambah pendapatan masyarakat didesa pringgesele dengan mengolah bahan mentah berupa jagung dan singkong menjadi barang jadi yang memiliki nilai tambah dan dapat membuka lapangan kerja bagi masyarakat sekitar dengan adanya produk olahan jagung dan singkong tersebut karena selama ini hasil panen produk pertanian berupa jagung dan singkong cukup banyak di desa pringesele.

Kata Kunci: jagung dan singkong; pengolahan produk; pengemasan produk

\section{PENDAHULUAN}

Pengembangan usaha sangat diperlukan untuk menunjang keberlangsungan usaha dimasa yang akan datang, tanpa adanya Pengembangan usaha maka akan sulit untuk menjaga keberlangsungan usaha. Salah satu instrument pengembangan usaha adalah penerapan manajemen usaha yang komprehensip, dimana manajemen usaha dapat berupa manajemen permodalan, manajemen keuangan, manajemen pemasaran dan manajemen operasional, tanpa adanya penerapan 
manajemen pada setiap usaha maka akan menyebabkan usaha akan sulit berkembang dan dapat mengancam keberlangsungan usaha dimasa yang akan datang.

Desa pringgesele merupakan desa yang terletak di kecamatan pringgesele kabupaten Lombok Timur, dimana sebagaian besar mata pencaharian warganya sebagai pedagang dan sebagai petani.Pertanian adalah sector yang paling banyak digeluti oleh masyarakat di desa pringgesele, masyarakat didaerah tersebut banyak menanam produk-produk pertanian seperti padi, jagung, singkong, ubi dan berbagai jenis tanaman atau produk pertanian lainnya.untuk produk jangung dan singkong di daerah ini tersedia banyak di areal pertanian warga dan bahkan cukup berlimpah. Produk hasil pertanian berupa jagung dan singkong yang hanya dijual dengan cukup murah karena produk pertanian yang dijual adalah produk mentah sehingga pendapatan masyarakat sangat sedikit sekali dari hasil jagung dan singkong.

Dengan adanya produk pertanian yang berlimpah khususnya jagung dan singkong di desa pringgesele maka diperlukan adanya pengembangan usaha dalam bentuk penerapan manajemen usaha terutama manajemen produk, pemasaran dan permodalan agar produk pertanian yang awalnya tidak memiliki nilai tambah maka akan dapat memberikan nilai tambah ekonomi kepada masyarakat di desa pringgesele dalam bentuk peningkatan pendapatan warga dari pendapatan yang rendah dari menjual produk jagung dan singkong menjadi produk yang memiliki nilai ekonomi tinggi sehingga dapat meningkatkan pendapatan masyarakat di desa pringgesele kabupaten Lombok Timur sehingga diperlukan pengabdian masyarakat dengan judul "Pelatihan Pengembangan usaha jagung dan singkong bagi masyarakat di desa Pringgesele Lombok Timur".

\section{METODE}

Dalam mengatasi permasalahan yang di hadapi mitra dalam kegiatan PPM Kemitraan ini, maka kegiatan yang dilakukan oleh tim adalah sebagai berikut: 1) Pelatihan dalam mengolah jumlah jagung dan singkong, 2) pelatihan pengemasan produk, 3) pelatihan pemberian merek, 4) pendampingan kegiatan produksi.

Dalam kegiatan produksi digunakan alat pengolah jagung dan singkong untuk dapat meningkatkan jumlah produksi , dimana alat ini akan berfungsi untuk membuat mengolah jagung dan singkong tepung dengan cepat, dengan jumlah yang banyak. Sedangkan untuk pengemasannya digunakan alat perekat plastik untuk mengemas produk dengan rapi dan memiliki daya tahan yang lama.

Tahapan-tahapan dalam kegiatan PPM Kemitraan ini melalui tahapan persiapan,pelatihan,pendampingan,evaluasi dan laporan, dimana setiap tahapan di tampilkan sebagai berikut:

\section{Tahapan Persiapan}

Pada tahap persiapan ini kegiatan yang dilakukan oleh tim pengabdian pada masyarakat terdiri dari pengadaan alat pengolah jagung dan singkong, dimana alat pengolah jagung dan singkong ini dapat meningkatkan jumlah produksi jagung dan singkongdari kelompok mitra, selain itu juga alat pengolah jagung dan singkongini juga dapat meningkatkan kualitas produkjagung dan singkong yang dihasilkan, selain itu juga pada tahap persiapan ini tim pengabdian juga melakukan pengadaan alat

pengemas Headseller yang berfungsi untuk merekatkan plastik dengan baik dan rapi sehingga jagung dan singkong yang ada di dalamnya terlindungi dan dapat bertahan lama.

Pada tahapan ini juga tim pengabdian juga melakukan komunikasi dengan mitra ,instruktur,pemateri lainnya untuk melakukan koordinasi berkaitan dengan teknik pelaksanaankegiatan pengabdian pada masyarakat, terutama yang berkaitan dengan pemberian materi dan prektek membuat dan memberikan merek yang baik pada suatu produk. Pada tahap ini 
juga mitra menyiapkan semua perlengkapan, bahan, tempat atau lokasi yang berkaitan dengan teknis pelaksanaan kegiatan pengabdian pada masyarakat ini dalam bentuk pelatihan.

\section{Tahapan Pelatihan Pengolahan Jagung dan singkong}

Pada tahapan ini mitra akan diperkenalkan oleh tim pengabdian pada masyarakat mulai dari cara penggunaan alat pengolah jagung dan singkong sampai dengan perawatan alat tersebut agar tidak mudah rusak, kegiatan ini memberikan peran aktif mitra untuk dapat secara langsung menggunakan alat pengolah jagung dan singkong dengan mendapat arahan dan bimbingan dari tim pengabdian pada masyarakat, karena peran aktif dari mitra merupakan bagian kesuksesan dari kegiatan pengabdian pada masyarakat ini.

\section{Tahapan Pelatihan Pengemasan Produk}

Pada tahapan ini mitra akan diperkenalkan cara mengoperasikan dan penggunaan alat pengepres (perekat) kemasan plastik sekaligus akan dibimbing cara mengepres dan memberikan perekat pada plastik kemasan agar tahan lama dan tidak mudah rusak, pada tahapan ini peran aktif mitra juga sangat penting karena akan berdampak secara langsung dalam memahami cara pengemasan produk yang baik.

4. Tahapan Pelatihan Manajemen Merek

Pada tahapan ini mitra akan diberikan pemahaman tentang cara pemberian merek yang baik, serta menambahkan atribut-atribut merek pada suatu kemasan produk agar konsumen dapat memperoleh semua informasi berkaitan dengan suatu produk. Metode penyampaian materi menggunakan penyampain dua arah dan peran serta dari mitra. Pada tahap ini mitra juga berkewajiban untuk mempersiapkan alat-alat atau bahan yang dibutuhkan seperti Plastik gelas cup PE.

\section{Tahapan Pendampingan}

Tahapan pendampingan bertujuan untuk memberikan pemahaman secara komprehensip berkaitan dengan teknis atau cara pengoperasian alat atau peralatan yang akan digunakan dalam kegiatan ini sehingga diharapkan akan dapat mengatasi berbagai permasalahan yang dihadapi mitra yang berhubungan dengan produksi, kemasan dan merek. Mitra juga diharapkan untuk menyampaikan berbagai permasalahan yang dihadapi dengan tim pengabdian pada masyarakat agar permasalahan tersebut dapat segera dicarikan solusinya.

\section{Tahapan Evaluasi dan Pelaporan}

Kegiatan evaluasi dan pelaporan menjadi bagian akhir dari kegiatan PPM Kemitraan, evaluasi dilakukan untuk memperoleh informasi secara utuh mengenai target, sasaran yang sudah terpenuhi dan untuk memperoleh gambaran yang berhubungan dengan berbagai kekurangan yang perlu diperbaiki pada kegiatan pengabdian pada tahun-tahun selanjutnya.

Kegiatan evaluasi dalam kegiatan pengabdian pada masyarakat ini dilakukan melalui cara-cara seperti (1) Curah pendapat antara Tim pengabdian PPM Kemitraan dengan mitra (2) Hasil pencatatan kegiatan PPM Kemitraan pada laporan Logbook kegiatan (3) Hasil pengamatan tim PPM Kemitraan selama segiatan berlangsung

Informasi dan catatan-catatan tersebut menjadi bahan di dalam penyusunan laporan akhir pengabdian pada masyarakat ini.

\section{HASIL DAN PEMBAHASAN}

Hasil dari kegiatan pengabdian kepada masyarakat ini adalah masyarakat di desa pringgesele dapat mengembangkan produk olahan jagung dan singkong yang bernilai tinggi sehingga menambah pendapatan masyarakat didesa pringgesele dengan mengolah bahan mentah berupa jagung dan singkong menjadi barang jadi yang memiliki nilai tambah dan dapat membuka lapangan kerja bagi masyarakat sekitar dengan adanya produk olahan jagung dan singkong tersebut karena selama ini hasil panen produk pertanian berupa jagung dan singkong cukup banyak di desa pringesele. Kegiatan pengabdian kepada masyarakat ini berjalan dengan baik dan lancar sesuai dengan yang diharapkan, hal ini terlihat dari Partisipasi dan Kehadiran dari peserta pelatihan pengabdian pada masyarakat yang berkaitan dengan pengolahan jagung dan singkong di desa pringgesele memenuhi target yang 
diharapkan oleh tim pengabdian pada masyarakat baik dari jumlah peserta pelatihan maupun sasaran materi yang disampaikan, karena jumlah kehadiran pengusaha jajanan kering yang berjumlah sebanyak 15 orang peserta, dimana peserta mendapatkan pelatihan pengabdian pada masyarakat berupa materi-materi pelatihan pengolahan jagung dan singkong menjadi produk bernilai tambah seperti materi Manajemen produksi (meningkatkan nilai tambah produksi), cara pengemasan produk jagung dan singkong yang baik dan menarik, dimana jagung di goring/sangrai dan di wadahi dengan gelas cup plastic yang menarik, sedangkan produk olahan sigkong di dikemas dengan plastic kemasan yang menarik dengan materi Teknik Pengemasan produk dengan plastik PE dan pemberian merek pada keripik singkong tersebut sesuai dengan ukuran dan isi keripik singkong tersebut.

Berdasarkan tingkat partisipasi peserta pelatihan kegiatan pengabdian pada masyarakat ini berlangsung dengan baik dan lancar. Ukuran keberhasilan dari kegiatan pengabdian pada masyarakat ini adalah jumlah peserta yang memenuhi target yang direncanakan, maka boleh dikatakan kegiatan ini berhasil dan terlaksana dengan baik.

Hambatan dan keberhasilan selama kegiatan pengabdian pada masyarakat ini adalah sebagai berikut:

a) Hambatan

Hambatan yang dihadapi oleh peserta pelatihan adalah banyaknya peserta yang masih sibuk bekerja sehingga tidak dapat mengikuti kegiatan pengabdian pada masyarakat sehingga tidak dapat mengikuti kegiatan pelatihan

b) Pendorong keberhasilan

Peserta pelatihan sangat antusias dalam mengikuti kegiatan pengabdian pada masyarakat yang berkaitan dengan peningkatan jumlah produksi dan pengemasan produk karena peserta dapat langsung berinteraksi dengan pemateri berkaitan dengan tatacara pengemasan dan pemberian merek yang baik oleh pengusaha jajanan kering. Selain itu juga peserta sangat aktif bertanya pada sesi tanya jawab selama kegiatan pengabdian pada masyarakat berlangsung karena kegiatan pelatihan peningkatan produksi ini sangat penting dan berimplikasi langsung pada peningkatan hasil produksi dan produk langsung dapat dikemas dengan baik dan pemberian merek dapat langsung dilakukan oleh pengusaha jajanan kering di desa pringgesele kabupaten Lombok Timur.
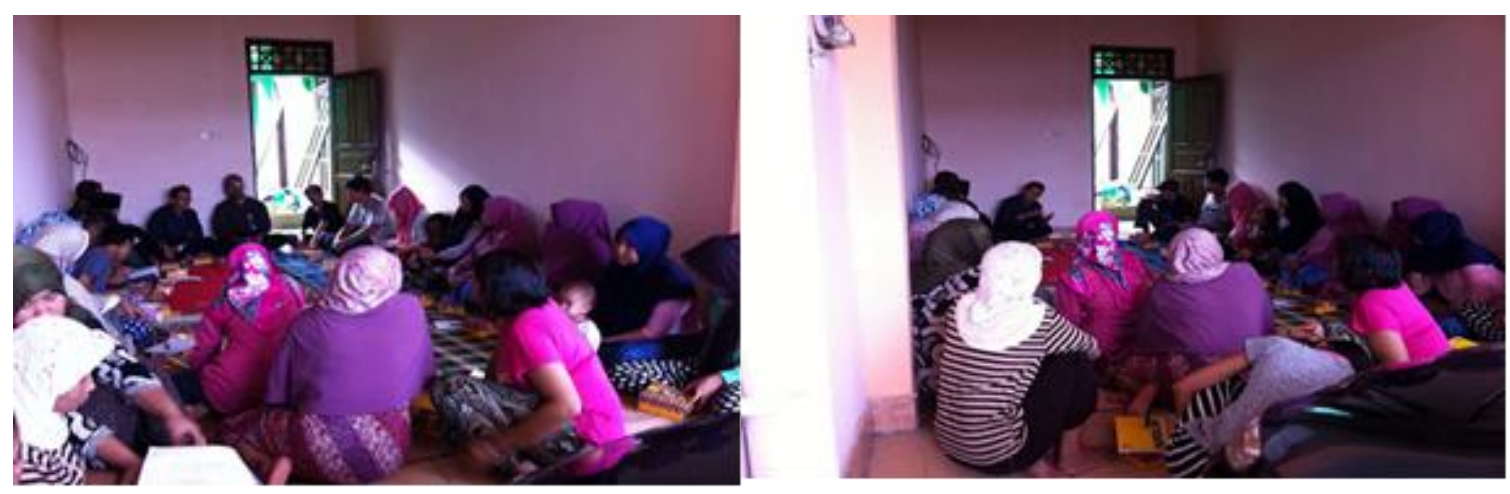

Gambar 1 Peserta mengikuti pelatihan dalam kegiatan pengabdian di desa pringgesele

\section{Kesimpulan}

\section{KESIMPULAN DAN SARAN}

Kegiatan pengabdian pada masyarakat telah dilaksanakan dan berjalan dengan baik dan lancar tanpa adanya halangan yang berarti serta antusiasme para peserta yang cukup baik yang dapat dilihat dari jumlah peserta yang hadir sebanyak 15 orang peserta dan cukup interaktif dalam diskusi tentang pengolahan jagung dan singkong serta cara pengemasan jagung dan singkong yang diharapkan akan dapat memberikan nilai tambah bagi masyarakat di desa pringgesele Lombok Timur. Adanya Kegiatan 
pengabdian kepada masyarakat dalam bentuk pelatihan ini, masyarakat yang mengolah jagung dan singkong dapat meningkatkan nilai tambah kedua produk tersebut melalui peningkatan kualitas produksi yang dihasilkan sehingga produk jadinya pun akan bernilai tambah sehingga akan meningkatkan pendapatan masyarakat sekitar yang hanya selama ini mengandalkan pendapatan dari suami saja tanpa adanya kegiatan berwirausaha.

Masyarakat di desa pringgesele yang mengolah jagung dan singkong sangat memahami arti pentingnya kemasan sebagai salah satu kekuatan dari suatu produk, kualitas produk juga tergantung dari kemasan yang digunakan dan kemasan harus tahan lama, higienis dan baik, oleh karena itu dengan adanya pelatihan pengolahan jagung dan singkong ini masyarakat dapat memahami pentingnya pengemasan yang baik dan menarik agar produk olahan jagung dan singkong ini laku dipasaran. Pengabdian kepada masyarakat di desa pringgesele ini juga dilakukan untuk memberikan pelatihan dan pemahaman tentang tatacara pemberian merek dan keharusan penggunaan merek yang baik dan bagus karena suatu produk dikenal baik oleh konsumen tergantung dari merek yang melekat pada suatu produk. agar mudah diingat oleh konsumen.

\section{Saran}

Kegiatan pengabdian pada masyarakat ini merupakan langkah awal bagi masyarakat di desa pringgesele agar dapat meningkatkan pendapatan mereka dengan berwirausaha dalam menghasilkan produk singkong dan jagung dikemudian hari dengan adanya kegiatan pengabdian pada masyarakat ini. Untuk memaksimalkan hasil kegiatan pelatihan ini perlu adanya kegiatan pengabdian selanjutnya yang berkaitan dengan pengemasan dan pemberian merek pada suatu produk terutama produk yang berkaitan dengan produk olahan jagung dan singkong

Agar pengabdian pada masyarakat ini dirasakan langsung manfaatnya oleh para peserta, maka perlu adanya evaluasi dan pendampingan terhadap para peserta / masyarakat di desa pinggesele yang berkaitan dengan pengolahan jagung dan singkong yang memiliki nilai tambah agar benar-benar mempraktikkan materi yang telah diterima pada pelatihan/penyuluhan yang diterima oleh masyarakat di desa pinggesele terutama dalam mengemas dan memberi merek pada suatu produk, terutama pada produk olahan jagung dan singkong..

\section{Ucapan Terima Kasih}

Tim pengabdian mengucapkan terima kasih kepada LPPM UNRAM yang telah memberi dukunganKeuangan terhadap terselenggarakannya kegiatan pengabdian ini.

\section{DAFTAR PUSTAKA}

Gunarsa \& Yuyun.A. 2011. Cerdas mengemas produk makanan dan minuman. Cetakan pertama. Agromedia Pustaka. Jakarta

Subanar.1998. Manajemen Usaha Kecil. Edisi Pertama. BPFE Universitas Gadjah Mada. Jogjakarta. Umar, Husain. 2003. Business an Introduction. Gramedia Pustaka Utama, Jakarta.

Susanti, Ariani.2008 Modul pelatihan desain merek dan kemasan.Direktorat jenderal industry kecil dan menengah Departemen Perindustrian.Mataram. 